なったので報告する。

X P E F の組成は

$\begin{array}{lllll}\text { 水 } & \text { 素 } & 6.9 \% & \text { 酸 素 } & 22.0 \% \\ \text { 炭 } & \text { 素 } & 71.0 \% & \text { コバルト } & 0.6 \% \\ \text { 比 } & \text { 具 } & 1.2 & & \end{array}$

電子密度 $3.22 \times 10^{23} / \mathrm{cm}^{3}$

(1)透過線舅はXPE F, 水, MIXDPKついて比较

(2)哚部量の比較

(3)散乱角度分布の测定（水平分布）

[結果及び考察]

従来，人体ファントームとして使用されてきたM I X D Pとポリエステル樹脂系と比較すると，今回の奏験範 团ではファントームの厚みが増加すると, 次第に差が出 て，また電压が高くなると差が少なくなる。しかしなが ら，小児ファントームの条件としては，約 $3 \sim 5 \%$ 差 にすきず，また散乱線測定の結果からしてす，測定䛊差 を考慮すれば，放射線管理のための散乱線測定や放射線 治療時の測定等十分使用出来ると思われる。

\section{貿 問}

(1) 肺組織として用いたコルクの，実効原子番鸢，電 子密度, 比重は

（2）ファントームの製作会社と，製作費用は

（茨城・阔部正則（

\section{答}

(1) 比重: $0.27 \mathrm{~g} / \mathrm{cc}$.

注 J.S.Laughlin, $0.38 \mathrm{~g} / \mathrm{cc}$. H.T.EIchhorm, $0.27 \mathrm{~g}$ /cc. 尾内 $0.21 \mathrm{~g} / \mathrm{cc}$.

原子番号，電子密度は奏測してないのでわからない。

（2）京都科学標本株式会社

$\begin{array}{lr}3 \text { 力月児 } & 80 \text { 万円 } \\ 4 \text { 才坚 } & 120 \text { 万円 } \\ 7 \text { 才坚 } & 190 \text { 万円 }\end{array}$

\section{4 表層深部線量分布の近似的測定法}

東京医科大学癌センター 放射線部

○田中 吉男 沢柳 久嘉 国府田幸雄

藤田 良三滝田 武信 橋本 茂男 (指導) 放射線医学総合研究所物理研究部

稻田 哲雄

[目的] ${ }^{60}$ Co. $\gamma$ 線及ベータートロン電子線について 表層深部線量分布孛求める場合, フイルム法により比較 的簡単にその近似的测定を行えると考え次の方法により 灵験圶行ったのでその結果について報告する.

[万法] ${ }^{60} \mathrm{Co} . \gamma$ 線についてはポリエステル樹脂 0.132 $\mathrm{g} / \mathrm{ch}$ の板を $1 \mathrm{~cm}$ 巾の六段階を作り Mix-DPのファント
ムの上にフイルムをのせ，その上にポリ階段をのせて S S D70 cmで照射しそのフイルムの濃度差により線量を 测定した。電子線についてはF S D 95cmで各種のッーブ ス芠用いた上記のポリ階段では電子線の場合, 線束分布 が不均質なため不適当なので，フイルムとポリエステル

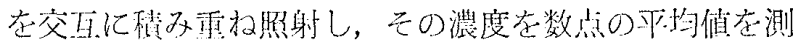
定した。

〔結果】I．電離法の测定とほぼ一致するので近似的 に正しいと思われる。 II Cdフイルターの影響は小さ い, 着衣の状態, 治療台の影響は大である。 III. 電子線 はスキャッタラ, ッーブス, Mix-DP Collimator によ る照射野整形の影響は大である。

$1515 \mathrm{Mev}$ ライナックの諸特性と使用経験

信州大学病院 中央放射線部

(部 長 小林敏焳教授 副部長 鈴木茂雄) ○丸山二三男 竹村 克人 安藤 隆 降旗 英等 横井 憲明 高本 信治

45年 4 月 $15 \mathrm{Mev}$ ライナックが設置され本年 1 月より 本確的治療を開始している。本装置はX線 $8,10 \mathrm{Mev}$, 電子線 $8 ， 10 ， 12 ， 15 \mathrm{Mev}$ のネルギーを屯つ. との 装瞋の性能と諸特性と現在まで約 9 力月使用してきた故 障亡保守の状沉を報啙する. 故障については，（Ｉ）加速 器系 3 件，（II）パルサー系 2 件，（III）マイクロ波系 3 件, (IV) 補助電源部 5 件, (V) 冷却系 2 件発生してい る. 治療日数 179 日のうち4 日の休診となり, 稼動率は $97.7 \%$ でる。保守点検は每日治療前 1 時間之土矅日を あて，故障発生防止亡装置の等定化をはかっている，本 装圆はM L 15M形としては一号機であるので故障頻度が やや多く感ぜられるが，性能，安定性にはすぐれている あのがある。

\section{6 多エネルギー核種のスキャンへの応用}

神奈川歯科大学病院 放射線科 閉野 政則 宮田雄四郎 交井徹 戸張 宏彦

最近, ${ }^{87} \mathrm{Ga},{ }^{111} \mathrm{In},{ }^{75} \mathrm{Se}$, 等の癌親和性の R I が, 臨床的に使用され始めた。乙れ等の核種は，数種の $\gamma$ 線 のエネルギーを持っているが，一般には 1 種のエネルギ 一しか使用していない，乙れ等エネルギ一中 2 種を同時 に計数すれば, 計数率が増し有利でする。我々は 1 種の 埸合と 2 種の場合のR I イメージの比較とした。 シンチ スキャナーに波高升别器を 1 つ迫扣して行なった, ${ }^{67} \mathrm{Ga}$ は92. 182. $388 \mathrm{KeV} 111 \mathrm{In}$ は $173.247 \mathrm{KeV}$ 等の内各 2 つのエネルギーを加算してラインソース, 臟器スキャ ンした。との結果，同時に 2 つエネルギーをとらえた 
方が従来の 1 つのエネルギー法に比べ鮮明な像が得られ た。また，スキャン時間の短宿ができ，さらにR I の投 与量の減少ができる。

質 問

$\mathrm{NaI}$ 検出器の直径と厚さは（茨城 岡部正則）

答

東芝製，37 h の3 インチ

\section{7 フォトタイマの検討}

日本医科大学付属病院

川崎 茂樹 石田 勝哉 斉藤 一彦

滰田 礼子 金川 進

本発表は，近年学会総会等において発表されたいくつ 汃の論文と軌を一にするあのですります。

〔目的〕当施設にある，D T-A A 型透視撮影台に組 み込まれているフォトタイマを，いかにしたらうまく利 用できるかを検討した。

[方法]1．被写体厚～濃度曲線 2，管電圧～濃度 曲線，以上の曲線を，ファントムを用いて求め，適正な 撮影条件を定めた。

〔結果〕このフォトタイマは，被写体厚が厚くなるる 濃度が低下してゆく。この濃度低下をおぎなうために管 電王を調節する。即ち，被写体を薄い，標準，原い，の

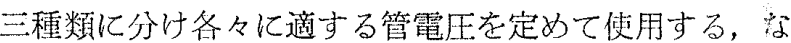
お，曝射時閆のわかる機構が設定されることが望まし い.

\section{質 問}

1) 私の診療所であ透視台にホトタイマーを組込んで いるが被写体厚と濃度との間には同じような傾向が 有り，現在はそ机をホトマルの感度を変化させて補 っているが，で検討のような管電圧によって補償で きれば実用的によい方法と思う。そのようなう法 で, 被写体厚さ15栍から26粗程度まで充分に濃度在 補うことができるでしようか。

2 ) 同じ方法 ; 即ち電圧で濃度を補う場合飞管球許容 負荷と制限から，管電流を低くしても同じ効果が期 待できると考えてよいでしようか.

（東京・森矢達人）

\section{答}

1) 当施設の透視撮影台に組み込まれているフォトタ イマーは管電圧調節によって，被写体厚 $14 \mathrm{~cm} \sim 24 \mathrm{~cm}$ まで撮影していますが，彰断可能な0.8〜1.3の適正 濃度の写真が得られています。

2) フォトタイマーの時間特性を調べておりませんの で抄答え出来か权ます。
18 胸部エックス線写真とシャーカステンの輝度の検 討（第一報）

結核予防会結核研究所他

川崎 幸槌 矢口. 忠 大山 幸吉
江間 忠 仲尾次政剛 中野 静男
村松 忠夫 多田 昇一

〔目的〕エックス線写真の読影々診断はあくまであ肉 眼でシャーカステンを通して行わ机るあのであるから， 写真のもつ情報を最大限传読みとるにはシャーカステン の輝度がごのように影響するかを検討したので報告す る.

〔方法】3,000から10,000ルックスまで輝度の調整で きるシヤーカステンを試作し, 照度計でシャーカステン の輝度を測定しながら変化させ，バーガー氏，ファント ム等各種ファントムを撮影した写真より各輝度に㧍汀る 認知能を求め, シャーカステンの最適輝度を選択した。 次に同様の実験を 120 枚の胸部エックス線写真について あ行ない，シヤーカステンの至適輝度を求めた．また数 施設のシヤーカステンの輝度および輝度分布の測定を行 ない，更に 210 施設より集めた管理のあり方についての アンケートをむとに検討を行った。

〔結語および考察】至適濃度の胸部エックス線写真の 観察には 6,000 ルックス以上の輝度をむつシヤ一カステ ンが望ましく，4,000 ルックス以下では認知能が明らか に低下する，またシャーカステンは蛍光管の経時変化に 上る輝度の低下が大きいので定期的に照度計でチェック し，照度の管理をするととが望ましい，监光管の特性と 経時変化により均一輝度でないので写真の観察にあたっ てはシヤーカステンの中央部を使用して観察することが 望ましい之考える。また窒内灯の位置，明るさ等読影環 境の整借も併せて行なうべきである、シャーカステンの 輝度等についての規格は現在定められていないので早急 に規格を設定し，輝度を均一化することが望ましいと考 える。

質 問

1 ）認知能の測定の測定はどのような方法でされたで しょうか。

2 ) シャーカステンのおかれている室の明るさと, 認 知能の関係は検討されたでしようか。

（東京・森矢達人）

\section{答}

1 ）認知能の測定はバーガー氏ファントムの空穴（直 径約 $28 \mathrm{~mm}$ 位い）の確認数を持って，表わしたすので す。な怙観察者は 8 名で各々の確認数の平均值によ 